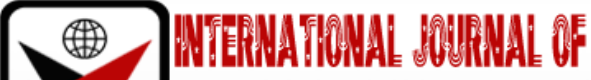 \\ X
}

ISSN 2278-0211 (Online)

\section{Effectiveness of Using Play and Song Strategies to Develop Pre-Reading and Pre-Writing Skills among Preprimary Pupils in Meru District, Tanzania}

Pascal V Andrew
Student, Department of Educational Psychology Measurement,
Mwenge Catholic University, Tanzania
Malusu JM
Associate Professor, Department of Educational Psychology Measurement, Evaluation and
Curriculum Studies, Mwenge Catholic University, Tanzania
Dr. Timothy Mandila
Senior Lecturer, Department of Educational Psychology Measurement, Evaluation and
Curriculum Studies, Mwenge Catholic University, Tanzania

\begin{abstract}
:
This study was conducted to assess the effectiveness of using play and song strategies towards developing pre-reading and pre-writing skills among preprimary pupils in Meru district, Tanzania. The study specifically assessed the extent to which the play and song strategies are used in the public primary schools as well as determined the teachers' level of knowledge and skills for them to effectively implement the strategies. The study was guided by constructivist theory developed by Bruner in 1966. The study adopted mixed methods approach using convergent design. The design helped in the collection of qualitative and quantitative data concurrently. Preprimary teachers and the head teachers in public primary schools in Meru district were targeted. Both probability and non-probability sampling techniques were used to select the study sample which consisted of 20 preprimary teachers and20 head teachers. Data were collected through the use of questionnaires, interview guides and observation guides. Descriptive statistics was used to analyze the quantitative data in terms of frequencies and percentages with the aid of SPSS whereby the hypothesis was tested using correlation analysis at 0.05 levels of significance. Qualitative data were analyzed in themes and presented in narrative being supported by direct quotations. The study found out that play and song strategies are not effectively used by the teachers to develop pre-reading and pre-writing skills in the district. The major reason was that teachers don't have the required skills as well as lack of resources. Results from hypothesis testing showed no significant relationship between the application of play and song strategies and teachers' possession of knowledge and skills on the strategies ( $p$-value $=0.241$ ). The study therefore recommended for workshops and seminars to be conducted so as to equip these teachers with the necessary skills and knowledge.
\end{abstract}

Keywords: Effectiveness, pre-writing, pre-reading, preprimary, strategies, play and song

\section{Introduction}

Education is defined as the process through which desired knowledge, skills and values are acquired (Oluoch,2006). From this old time, education has not been seen as an event but rather a process. It is considered to be a process meaning that it does not end throughout one's life. This being the case, education systems in the world are categorized into different stages and in each stage particular learning is expected to take process. At the lower stages the acquisition of basic skills is expected and as one moves on, he or she becomes exposed into more complex skills. Taking an example of the Tanzanian education system as stipulated in the education and training policy of 2014, pupils are required to attend at least one year of pre-primary education, seven years of primary education, four years of ordinary secondary education, two years of advanced education and three or more years of university education depending on the requirements of a specific course (URT, 2014).

Pre-primary education has been presumed to have an influence on children's' literacy skills development in primary school. According to Manu et al (2021), pre-reading skills significantly predict students reading comprehension. This means that pupils who acquire pre-reading skills show significant development in reading abilities when compared to the ones without such skills. Pre-reading and writing skills have been found to highly contribute to brain development of pupils and thus facilitating both their cognitive and social wellbeing (Rusu et al, 2019). Therefore, engaging students in pre-reading and pre-writing activities helps them to improve their reading and writing abilities (Zarfsaz\&Yeganehpour, 2021; Osei, et al 2016). According to the theories of language development, involving children in pre-reading and writing 
activities at the early age (three to four years) improves their reading and writing skills much greatly than at the later ages (Jenkins et al, 2016). Different activities which may enhance reading readiness may include, proper turning of pages, associating pictures and live experiences and movement of the eyes left to right (Osei, et al 2016). Other activities include phonological awareness, holding pens, oral language are the main focus of pre-primary education (Harris, et al 2017).

According to Early Grade Reading Assessment (EGRA, 2016), the ability to read and understand text is one of the most fundamental skills that a child can learn. This implies that teaching pupils the pre reading and writing skills is fundamental for their success in all the other aspects of learning. This is because most of the learning process in schools across different levels of education requires one to be able to read and write. Moreover, a person who knows how to read and write is considered to be literate while the one without such skills is regarded as an illiterate (Roskos et al, 2003). Therefore, the ability to read and write is highly needed for academic and social development of each person. These skills are best learnt at the lower stages of education particularly in pre-primary.

Effective implementation of most pre-reading and pre-writing skills to the pre-primary pupils highly depends on the strategy used by teachers. The highly recommended teaching strategy is the use of play and song. According to Lesser et al (2019), the use of songs in the teaching and learning process makes the learning to be enjoyable, improves memory and increases the level of pupils' engagement in the learning process. When the pupils enjoy learning and they maximally engage in the pre reading and writing activities the possibility for them to acquire these skills increases. Additionally, the use of play and song methods reinforces pupils' attention on learning the available materials and therefore leads into pupils' acquisition of the pre reading and writing skills which are fundamental for their reading and writing comprehension (Franceschini et al., 2013).

The application of play in the teaching of pre reading and writing skills to the preprimary pupils creates harmony and cultivates interests learning interest among pupils (Musa et al. (2012). Play and song strategy therefore are seen as the most advantageous tools for teaching the acquisition of language skills among pre-primary pupils (Klimova, 2013). The application of play and song strategies also provides learners with the best learning environment that allows competition among them while maintain their love and positive interaction (Mourão, 2014). Therefore, teachers of pre-primary pupils are advised to plan and make use of play and song strategies so as to arouse pupils' interest in reading and writing (Jung \&Gusan, 2012). These methods help to the development of pre reading and writing skills which are essential for language and holistic development of the pupils. Teachers' high level of knowledge is instrumental to devising challenging but accommodative learning environments, hence improving learning outcomes. In fact, knowledgeable teachers can anticipate the learners' difficulties and adaptively respond to meet their needs (Keller, Neumann, \& Fischer, 2017). In the light of this, this study intended to find out the relationship between teachers' knowledge and the application of play and song strategies.

Literacy teaching has been a topic of debate in many countries because some pupil achievement in aspect of literacy is not promising as reasonable number of primary schools pupils graduate without literacy (Gathumbi, 2013; Twaweza, 2019; Ligembe, 2014; Anney et al, 2016). Different studies have been undertaken to unveil the reasons for poor mastery of reading and writing skills among pupils. However, little attention has been paid on how effective do teachers make application of play and song strategies to develop students' mastery of pre-reading ad pre-writing skills in Tanzania particularly in Meru district. Therefore, this study was conducted to assess the effectiveness of applying play and song strategies towards improving the acquisition of pre reading and writing skills among preprimary pupils in public primary schools in Meru district.

\subsection{Problem Statement}

Reading and writing abilities are essential for academic progress across all levels of education. Due to their importance, reading and writing abilities in children have been focal points of many education stakeholders (Mckey, 2002; Huyen\&Nga, 2003). These abilities are best learnt at the early stages of child's development (Jenkins et al, 2016). This is why most of the countries emphasize on the teaching of pre reading and pre writing skills to the preprimary pupils (Zarfsaz\&Yeganehpour, 2021; Osei, et al 2016). Pre reading and writing skills are considered to be essential for the academic development of pupils as well as the acquisition of reading and writing skills (Manu et al, 2021). Literature suggest that proper teaching of pre reading and pre writing skills can be effective if the teachers make use of play and song strategies (Lesser et al, 2019; Musa et al, 2012; Klimova, 2013; Mourão, 2014). However there are still concerns of some students to demonstrate poor mastery of reading and writing skills in later stages of education (Twaweza, 2019; Ligembe, 2014; Anney et al, 2016). Different factors for such scenario have been investigated but little attention has been paid on the application of play and song strategies in public primary school in Meru district. Therefore, the current study filled the gap by assessing the effectiveness of applying play and song strategy towards improving the mastery of pre reading and pre writing skills among preprimary pupils in public primary schools in Meru district.

\subsection{Research Questions}

- To what extent are play and song strategies used in developing pre reading and pre writing skills among preprimary pupils in Meru district?

- How well are pre-primary teachers equipped with skills to use play and song strategies when teaching pre reading and pre writing in Meru district?

\subsection{Research Hypothesis}

There is a significant relationship between teachers' possession of preprimary skills and the application of play and song strategy. 


\subsection{Theoretical Framework}

This study was guided by constructivist theoretical framework by Bruner (1966). Bruners' theoretical framework is based on the theme that learners construct new ideas or concepts upon existing knowledge. Bruner's (1966) constructivist learning theory of instruction addresses four major aspects: first predisposition towards learning second the way in which the body of knowledge can be structured so that it can be most readily grasped by the learner third the most effective sequence in which to present material to be learned, and lastly the nature and pacing of rewards and punishments.

It hypothesizes that learning is an active process in which learners construct new ideas or concepts based upon their current and past knowledge and that the learner selects and transforms information, constructs hypothesis, and makes decision, relying on a cognitive structure to do so. Therefore for the case of discovery learning and motivation of interest to learning, preprimary teachers should use suitable strategy so as preprimary pupils can discover knowledge for themselves when learning pre reading and pre writing skills also preprimary teachers should provide frequent learning activities, songs, games, drawings and play. Therefore availability of various resources and well speaking class with full facilities for the preprimary pupils, frequent assessment and evaluation of the pupils should be in developing active in learning pre reading and pre writing skills and construct their own knowledge on pre reading and pre writing.

According to constructivist theory for the strategies that are used by preprimary teachers to be effective will depend on the application of learner centered approach. Teaching and learning strategy including teaching and learning resources, assessments and evaluation process, should be focused on to learner centered approach. Play and song strategy are crucial in developing preprimary school pupils to be able to discover the knowledge for themselves in the classroom lessons and outside the classroom.

\section{Literature Review}

Baidoo (2016) conducted a study to investigate the existing teaching strategies for teaching at kindergarten, their usage in the classroom as well as their impact on pupils' performance in Ghana. The study employed qualitative research approach whereby data were collected from 140 participants included preschool teachers and KG1 and KG2 pupils through questionnaire, observation, and interview. The study found out that KG 1 and KG 2 teachers in the school were not in touch with current strategies because their lessons centered mostly on plays and songs were used to teach letter names and sounds. Moreover, the study found out that teachers employed child centered teaching approaches because songs and plays made the kindergarten pupils very active in class and got them fully involved.

Another study was conducted by Budinski and Lujić (2018) to examine the preschool teachers' opinions on the methodology of teaching activities for developing pre-reading and pre-writing skills in Zagreb, Croatia. The study employed qualitative research approach whereby data were collected from 6 preprimary teachers from two preprimary in Zagreb through interview. The study found out games was mostly used as teaching approach but teacher designed activities according to pupils' interest. The results indicated that the teaching methodology applied by preschool teachers contributed to the development of pre-reading and pre-writing skills. Also the preschool teachers, depending on their competences, and in agreement with the policy and preschool curriculum, create the most favorable conditions for developing pre-reading and pre-writing skills.

Another study was conducted by Onyango and Gakii (2017) to investigate the influence of instructional strategies on pre-school children transition to lower primary school in Kikuyu Sub Urban, Kenya. The study employed exploratory approach using descriptive research design whereby data were collected from 48 participants through questionnaire and interview. The study found out that singing, reading and numbering were the mostly used strategies by teachers to enhance smooth transitioning of preschool children to lower children. The findings of the study indicated that teachers in preprimary used singing, reading and numbering instructional strategies on preprimary children to develop reading and writing skills.

Strauss (2017) conducted study to explore a dialogical approach for improving early literacy teaching in multilingual pre-primary contexts in South Africa. The study employed mixed research approach whereby data were collected from 33 participants through interview, questionnaire and pre \& post-test. The study found out that professional development changed teachers' beliefs and practices about teaching isolated phonics and reading skills against a focus on opportunity for rich talk, interaction and having an impact in culture moment. The study indicated that professional developments trainings equipped with skills and knowledge preprimary to overcome early literacy teaching challenges in multilingual context.

Matsumoto and Tsuneda (2019) conducted study to explore teachers' beliefs about literacy practices for young children in early childhood education and care settings. The study employed exploratory research design whereby data were collected from 394 participants included preprimary teachers and primary teachers through questionnaire. The study found out that preprimary teachers afford a better understanding of effective practices to facilitate the early literacy experiences of young children in preprimary settings beyond differences in their educational tradition concerning early literacy.

Shukia (2019) conducted study to investigate pre-primary Education in Tanzania: teachers' knowledge and instructional practices in rural areas. The study employed a descriptive survey research design whereby data were collected from 19 participants through questionnaire and observation schedule. The study found out that preprimary had little knowledge regarding early childhood education. Furthermore those teachers were knowledgeable on the importance of play to children and understood the objectives of pre-primary education. 


\subsection{Knowledge Gap}

The reviewed literature have shown the importance of using play and song strategies towards enhancing the acquisition of pre reading and pre writing skills among preprimary pupils (Baidoo, 2016; Budinski\&Lujić, 2018). Play and song strategies are emphasized since they engage pupils in many activities which in turn improve their reading and writing abilities (Baidoo, 2016). The studies also showed that teachers use play and song strategies on reading and numbering (Onyango\&Gakii, 2017;Strauss, 2017; Matsumoto \&Tsuneda, 2019). However, there is still limited literature on how effective are play and song strategies used to develop the pre-reading and pre-writing skills. Therefore, the current study was conducted to assess the effectiveness of implementing play and song strategies on developing pre reading and pre writing skills among preprimary pupils in public primary schools in Meru district.

\section{Methodology}

The study adopted mixed methods approach under which convergent design was used, this design helped the researcher to collect qualitative and quantitative data needed to address the research problem. The target population consisted of 157 heads of schools, 314 preprimary school teachers. From this population, both probability and nonprobability sampling techniques were used to select the study sample which consisted of 20 preprimary teachers, and 10 head teachers.

Questionnaires, interview guide and observation guide were used to collect the necessary data. Preprimary teachers responded to questionnaires while the head teachers were interviewed. Observation guide helped the researcher to collect information from observing teachers while teaching the preprimary pupils to determine whether they make use of play and song strategies. The collected quantitative data were summarized into means, frequencies and percentages and presented using tables and charts. The null hypothesis was tested using Pearson at 0.05 significant level and for qualitative data thematic analysis was used. The researcher adhered to all the ethical principles in research.

\section{Findings and Discussion}

\subsection{Extent Play and Song Strategies Are Used to Develop Pre-Reading and Pre-Writing Skills among Preprimary Pupils in Meru District}

The first research question aimed at finding out the extent to which play and song strategies are used in developing pre-reading and writing skills in Meru district. Responses to answer this question were obtained from teachers, head teachers and classroom observation. Table 1 summarizes the responses from teachers.

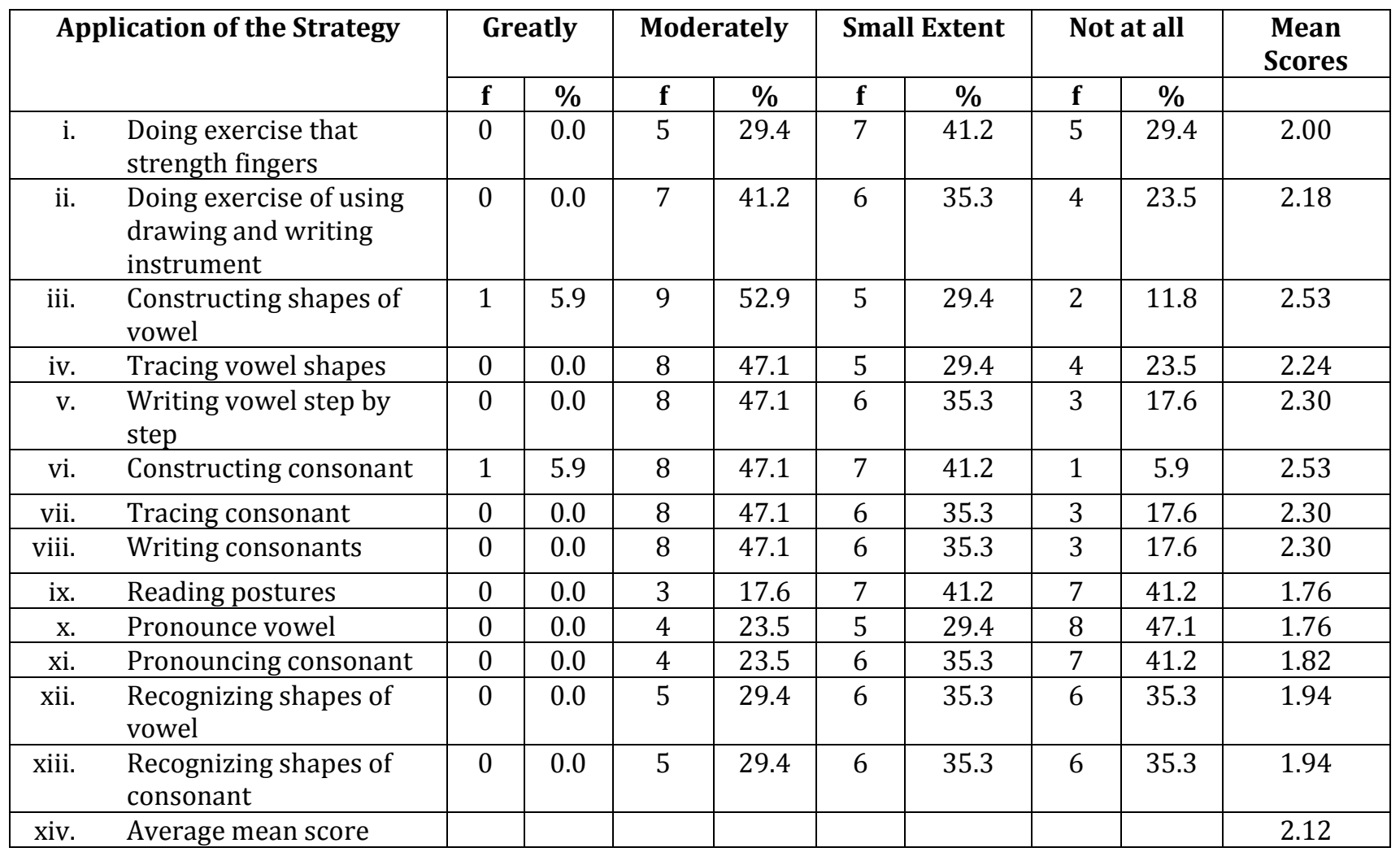

Table 1: Teachers' Responses on the Application of Play and Song Strategies

Source: Field Data, (2021)

Data in table 1 show that 52.9 of the teachers indicated to be using play and song strategies in teaching preprimary pupils how to construct shapes of vowels at a moderate extent while $29.4 \%$ indicated to be using the strategy at a small extent and $11.8 \%$ indicated not to have used the strategy at all. These findings imply that the application of play and song strategy on teaching pre-reading and writing skills is moderately done by half of the teachers while the other half either do it at a small extent or do not apply the strategy at all. Failure of teachers to effectively apply play and song 
strategies to teach pre-primary pupils how to construct vowels negatively affects the acquisition of pre-reading and writing skills. This is in line to what was concluded by Onyango and Gakii (2017) who found out the application of play and songs has a great impact on the learning of pre-reading and writing skills.

Results in table 1 show that $47.1 \%$ of teachers indicated tobe using song and play strategies in teaching preprimary pupils on how construct consonant at moderate extent while $41.2 \%$ of teachers indicated to be using the strategy at small extent and 5.9\% of teachers indicated not to have use the strategy at all and only 5.9\% of teachers indicated to be using the strategy to a greater extent. The findings imply that application of song and play strategy on teaching pre reading and pre writing is moderate. Though $5.9 \%$ of teachers indicated to be using play and song at small extent but still teacher uses the strategies it makes pupils to be very active and got fully involved and the activities motivate them to work sometimes without supervision as supported by Baidoo (2016) who found out that KG 1 and KG 2 teachers in the school were not in touch with current strategies because their lessons which were centered mostly on plays and songs were used to teach letter names and sounds.

Data in table 1 show that $47.1 \%$ of teachers indicated to be using song and play strategy in teaching preprimary pupils on how to write consonants on how to write consonants at moderate extent, $35.3 \%$ of teachers indicated to be using the strategies at small extent and $17.6 \%$ indicated not to be using the strategies at all. The finding indicate that Song and play strategies were used but not at greater extent this may because play and song though it help to make study active and fully involved but it consume a lot of time. Since the strategies consumes time probably teachers use it at beginning and at the end of period in order to attract children's attention and select another strategy which also help to develop pre reading and pre writing as supported by Budinski\&Lujić (2018) who contrary found out that games were mostly used as teaching approach but teacher designed activities according to pupils' interest.

Data in table 1 also show that $47.1 \%$ of teachers indicated to be using song and play strategies in teaching preprimary pupils on how to write vowel step by step, $35.3 \%$ of teachers indicate to be using at small extent and 17.6 of teachers indicated to be not using at all. The findings indicate that most of teachers prefer use of other strategies than song and play strategy because of they may very competent of using such strategy than songs and plays strategy as supported by Tandika (2017) who study revealed out shortage of qualified teachers in preprimary education affected efficiency in equipping children with pre reading and pre writing skills.

The average mean score for teachers application of play and song strategies was 2.12 which is less than the neutral mean score (2.5). This implies that preprimary teachers in Meru district make use of play and song strategies to a small extent. Such small extent of using the recommended strategies may negatively affect the development of pre reading and pre writing skills among preprimary pupils in the schools. The researcher further conducted classroom observation in five schools to determine whether the teachers make use of the play and song strategies. The summary of classroom observation is presented in table 2

\begin{tabular}{|ll|c|c|c|c|}
\hline & \multicolumn{2}{|c|}{ Strategy Observed } & \multicolumn{2}{c|}{ Applied } & \multicolumn{2}{c|}{ Not Applied } \\
\cline { 3 - 6 } & & f & $\%$ & f & $\%$ \\
\hline i. & Teacher introduces a lesson by using a song & 5 & 100.0 & 0 & 0.0 \\
\hline i. & Teacher relates how to read vowels a e i o u by using a play & 3 & 60.0 & 2 & 40.0 \\
\hline i. & Pupils are able to relate vowels with play & 1 & 20.0 & 4 & 80.0 \\
\hline r. & Teacher is able to involve all pupils & 0 & 0.0 & 5 & 100.0 \\
\hline j. & Teacher is able to evaluate pupils by using a song & 1 & 20.0 & 4 & 80.0 \\
\hline i. & Teacher end up a lesson with a play & 1 & 20.0 & 4 & 80.0 \\
\hline i. & Song strategies are effective for developing pre reading activity & 1 & 20.0 & 4 & 80.0 \\
\hline
\end{tabular}

Table 2: Results of Classroom Observation

In all the observed lessons, teachers were able to introduce lessons using songs. However, the songs seemed not to be clear to some of the students. During the lessons, some teachers were able to link the songs to what was being taught on that day while others used the songs without linking to the objectives of the lesson. For instance, one teacher from school 'D'was teaching the writing and reading of vowels in Swahili, the teacher used the following song;

Nina ndegewanguwatanooporiniiwanalialiakwasautizairabuu

Wa kwanza akiliaaanalia ' $a$ '

Wa pili akiliaaanalia ' $e$ '

Watatuakilaanalia ' $i$ '

Wanneakiliaanalia ' $o$ '

Watanoakilaanalia ' $u$ '

Wotewakiliawanalia a e i o u (9th July, 2021)

Translated

'I have five birds in the bush, they shout out in vowel sounds

The first one shouts out ' $a$ '

The second one shouts out ' $e$ '

The third one shouts out ' $i$ '

The fourth one shouts out ' $\mathrm{o}$ '

The fifth one shouts out ' $u$ ' 
When shouting all together they shout a, e, i, o, u'. (9th July, 2021)

Results of observation implies that this teacher used the song strategy appropriately when teaching pre-reading of the five vowels. According to Paige, et al (2019), the ability to recognize vowel sounds is an important stage towards developing pupils' ability to read. Therefore, as teachers emphasize on the application of song strategy on teaching vowel sounds, the possibility of pupils to develop the pre reading skills is enhanced. This argument is supported by a number of scholars including; Lesser et al, (2019); Musa et al, (2012); Klimova, (2013) who indicated that effective development of pre-reading skills can be achieved by the application of play and song strategy. Therefore, a teacher who uses play and song strategy in teaching vowel sounds is at a better position of developing pre-reading skills among the pupils compared to those who use other strategies.

Concerning the application of play and song strategies on developing, pre-writing skills, another teacher from school ' $A$ ' was observed to use a combination of play and song while teaching the construction of letter ' $a$ '. While demonstrating on the air using her index finger, the pupils were also following the action by the teacher while singing the following song in Swahili;

Kuandikanapendamaumboyairabu

walimuniwezeshekwakuliumba

hatuaya kwanza unzungusha,

hatuaya pili unapandisha,

hatuayatatuunashuka,

hatuanneunawekakikonyo

zungusha, pandisha,shushaa, kikonyo (14th July, 2021)

Translated

I like writing vowel shapes

Help me teachers to create it

The first step is to rotate,

The second step is to raise it up

The third step is to take it down

The forth step is to but the hook

Rotate, raise it up, take it down; hook (14th July, 2021)

As the pupils were singing and imitating the action by the teacher, they were learning how to construct small letter ' $a$ '. During the observation, students were seen to enjoy the lesson and were singing as well as doing what the teacher was instructing. This implies that when song and play strategies is well applied, it raises pupils' interest as well as enhancing the development of pre-writing skills. This is in agreement to Adinolfi (2012); Jung \&Sainato (2013) who put forward that effective application of play and song strategy makes the pupils interested in the learning process and helps the development of early learning skills. Therefore, teachers who effectively use play and song strategy make their pupils to learn best and develop the intended skills.

On the contrally, during the observation, some teachers were found to be using play and song strategies bat not linking to the aspects being taught. For Instance, one teacher from school ' $\mathrm{A}$ ' was teaching the reading of small and capital letters and the following song was used;

Parachichi, parachichi, papaii, papaii, tikitimaji, tikitimajiainazamatunda, ainazamatunda.

Parachichi, parachichi, mahindii, mahindii, nyamanakaranga, nyamanakarangaainazavyakula, ainazavyakula.

Translated

Avocado, avocado, pawpaw, pawpaw, watermelon, watermelon, types of fruits, types of fruits.

Avocados, avocado, maize, maize, meat and nuts, meat and nuts types of foods, types of foods.

There was no link between what was being taught on that day (reading of small and capital letters) and the song used. The song was on types of foods and fruits and the teacher made no attempt to link the foods and fruits to capital and small letters. This implies that some pre-primary teachers though make use of play and song strategies, such strategies are not well used and therefore the development of pre-reading and pre-writing skills cannot be well achieved.

\subsection{The Extent to Which Pre-Primary Teachers Are Equipped on Strategies to Developing Pre-Reading and Pre-Writing Skills} in Meru District

The second research question aimed at investigating the extent to which preprimary teachers in Meru district are equipped with the skills and knowledge for them to effectively make use of play and song strategies to develop the prereading and pre-writing skills among preprimary pupils. Information to answer this question was obtained from teachers and classroom observation. Table 3 presents the findings from teachers. 


\begin{tabular}{|c|c|c|c|c|c|c|c|c|c|c|}
\hline & \multicolumn{2}{|c|}{ Not at all } & \multicolumn{2}{|c|}{$\begin{array}{c}\text { Small } \\
\text { Extent }\end{array}$} & \multicolumn{2}{|c|}{$\begin{array}{l}\text { Moderate } \\
\text { Extent }\end{array}$} & \multicolumn{2}{|c|}{$\begin{array}{l}\text { Greater } \\
\text { Extent }\end{array}$} & \multirow[t]{2}{*}{$\begin{array}{l}\text { Mean } \\
\text { Scores }\end{array}$} \\
\hline & & f & $\%$ & f & $\%$ & f & $\%$ & f & $\%$ & \\
\hline i. & $\begin{array}{l}\text { Developing understand about } \\
\text { print material }\end{array}$ & 0 & 0 & 5 & 29.4 & 9 & 52.9 & 3 & 17.6 & 2.88 \\
\hline ii. & $\begin{array}{l}\text { Identify names of various } \\
\text { objects }\end{array}$ & 0 & 0 & 6 & 35.3 & 8 & 47.1 & 3 & 17.6 & 2.82 \\
\hline iii. & Pronouncing letter sounds & 0 & 0 & 5 & 29.4 & 9 & 52.9 & 3 & 17.6 & 2.88 \\
\hline iv. & $\begin{array}{l}\text { Relating vowel shapes with } \\
\text { their respective sounds }\end{array}$ & 0 & 0 & 6 & 35.3 & 9 & 52.9 & 2 & 11.8 & 2.77 \\
\hline $\mathrm{v}$. & Pronouncing letter sounds & 0 & 0 & 8 & 47.1 & 7 & 41.2 & 2 & 11.8 & 2.65 \\
\hline vi. & $\begin{array}{l}\text { Relating consonant shapes } \\
\text { with their respective sound }\end{array}$ & 0 & 0 & 7 & 41.2 & 10 & 58.8 & 0 & 0 & 2.59 \\
\hline vii. & Identifying pictures of objects & 0 & 0 & 7 & 41.2 & 9 & 52.9 & 1 & 5.9 & 2.65 \\
\hline viii. & $\begin{array}{l}\text { Practicing activities that build } \\
\text { fine motor }\end{array}$ & 0 & 0 & 9 & 52.9 & 8 & 47.1 & 0 & 0 & 2.47 \\
\hline ix. & $\begin{array}{l}\text { Practice using drawing and } \\
\text { writing materials }\end{array}$ & 0 & 0 & 8 & 47.1 & 8 & 47.1 & 1 & 5.9 & 2.59 \\
\hline $\mathrm{x}$. & Practicing pre writing & 0 & 0 & 8 & 47.1 & 9 & 52.9 & 0 & 0 & 2.53 \\
\hline xi. & Constructing vowel shapes & 0 & 0 & 8 & 47.1 & 8 & 47.1 & 1 & 5.9 & 2.59 \\
\hline xii. & Tracing vowel shapes & 0 & 0 & 10 & 58.8 & 6 & 35.3 & 1 & 5.9 & 2.47 \\
\hline xiii. & Writing vowel step by step & 0 & 0 & 12 & 70.6 & 3 & 17.6 & 2 & 11.8 & 2.41 \\
\hline & $\begin{array}{ll}\text { Constructing } & \text { consonant } \\
\text { shapes }\end{array}$ & 0 & 0 & 11 & 64.7 & 4 & 23.5 & 2 & 11.8 & 2.47 \\
\hline $\mathrm{xV}$. & Tracing consonant shapes & 0 & 0 & 12 & 70.6 & 3 & 17.6 & 2 & 11.8 & 2.41 \\
\hline xvi. & $\begin{array}{l}\text { Writing consonant step by } \\
\text { step }\end{array}$ & 0 & 0 & 9 & 52.9 & 6 & 35.3 & 2 & 11.8 & 2.59 \\
\hline xvii. & Average mean score & & & & & & & & & 2.61 \\
\hline
\end{tabular}

Table 3: Teachers' Responses on How Well They Are Equipped with Skills

Data in table 3 show that $52.9 \%$ of teacher indicated to be equipped at moderate extent on how to develop understanding about print material, $29.4 \%$ of teachers indicted to be trained at small extent and 17.6 indicated to be equipped at large extent on how to develop understanding about print material. These findings imply that most of teachers $52.9 \%$ who participated in this study have moderate understanding on how to develop understanding about print material. The findings indicated that preprimary teacher are not competent on strategies of developing pre reading and pre writing using printing material to develop understanding to preprimary pupils, therefore their knowledge and skills is limited as supported by Shukia (2019) who conducted a study to investigate preprimary Education in Tanzania, they found out that preprimary had little knowledge regarding early childhood education. Furthermore those teachers were knowledgeable on the importance of play to children and understood the objectives of pre-primary education. Therefore the study by Shukia, 2019 indicated preprimary teacher had moderate skills and knowledge.

Data in table 3 show that $52.9 \%, 52.9 \%$ of teacher indicated to be trained at moderate extent of pronouncing letter sounds and relate vowel shape with their respective sounds while $29.4 \%, 35.3 \%$ of teachers indicated to be trained at small extent respectively. Moreover $17.6 \%$ and $11.8 \%$ of teachers indicated to be trained at lager extent strategies of pronouncing letter sounds and relate vowel shape with their respective sound respectively. These finding implies that most of teachers $52.9 \%$ were moderate trained on strategies of pronouncing letter sounds and relate vowel shape with their respective sounds. Therefore for them to become more competent training is highly needed so as to be at a good position to develop pre reading and pre writing skills to children as supported by Strauss (2017) The study found out that professional development changed teachers' beliefs and practices about teaching

Data in table 3 also show $58.8 \%$ of teachers indicated as trained at moderate extent strategy on how to relate consonant shapes with their respective shapes while $41.2 \%$ of teachers indicated trained in small extent. The finding implies that most of teachers 58.8 were trained at moderate extent on strategies to relate consonant shapes with their respective shapes. Therefore there is a great need for preprimary teacher to attend high education program so as to acquire more knowledge and skills because workshop and training program won't be enough to equip all the skills and knowledge require for teaching preprimary as supported by Matsumoto\&Tsuneda (2019)who found out that preprimary teachers affords a better understanding of effective practices to facilitate the early literacy experiences of young children in preprimary settings beyond differences in their educational tradition concerning early literacy. The study indicated that preprimary teacher had high education qualification.

Result in table 3 show that $52.9 \%$ of teachers indicated to be trained at moderately extent on how to identify pictures of objects, $41.2 \%$ of teachers indicated to be trained at small extent and only $5.9 \%$ of teachers indicated to be trained at higher extent. These findings imply that most of teachers $52.9 \%$ were trained at moderate extent on strategies of identifying pictures of objects. These findings indicate that some strategies is applicable with availability of learning 
resource and does not require more training. The availability of learning resources help teachers gain more experience as one make use of it as supported by Maning et al (2017).

Data in table 3 show that $52.9 \%$ of teachers indicated to be trained on strategies of practicing pre writing at moderately extent while $47.1 \%$ indicated to be trained at small extent. These findings imply that most of teachers $52.9 \%$ were trained at moderately extent on strategies of practicing pre writing. This was supported by Namamba\&Rao (2017) who found out that preparation of teacher educators in Tanzania receives considerable attention in postgraduate programs and focus in undergraduate programs. Also was found by Abdi et al (2020) who argued that teachers were exposed to different concepts of reading skill as well as the skills of teaching those concepts differently depending on years of their graduation.

The researcher further computed the mean scores for application of play and song strategies and mean scores for teachers' possession of skills. Then tested the hypothesis using correlation analysis. The process of hypothesis testing has been described in the subsequent sections. The hypothesis was tested using correlation analysis at 95\% confidence level since it is the one accepted in social sciences and the results of this analysis are summarized in table 4

- Null Hypothesis: there is no significant relationship between teachers' application of play and song strategies and their possession of knowledge and skills on play and song strategies.

\begin{tabular}{|c|c|c|c|}
\hline \multicolumn{2}{|c|}{} & $\begin{array}{c}\text { Possession of } \\
\text { Skills }\end{array}$ & $\begin{array}{c}\text { Application of Play } \\
\text { and Song Strategies }\end{array}$ \\
\hline \multirow{2}{*}{ Possession of Skills } & Pearson Correlation & 1 & .379 \\
\cline { 2 - 4 } & Sig. (2-Tailed) & & .201 \\
\cline { 2 - 4 } & $\mathrm{N}$ & & 13 \\
\hline \multirow{2}{*}{$\begin{array}{c}\text { Application of Play And } \\
\text { Song Strategies }\end{array}$} & Pearson Correlation & .379 & 1 \\
\cline { 2 - 4 } & Sig. (2-Tailed) & .201 & 13 \\
\cline { 2 - 4 } & $\mathrm{N}$ & 13 & \multicolumn{2}{|c}{} \\
\hline
\end{tabular}

Table 4: Results of Hypothesis Testing

Results of statistical analysis show that $p$-value $=0.201$. Since the p-value $(0.201)$ is greater than the significant level (0.05), the null hypothesis was not rejected. This implies that there was no significant relationship between teachers' possession of skills and the application of play and song strategies. This might be due to the fact that most of the teachers were found to have moderate skills concerning the application of play and song strategies. Meanwhile, majority of them were found to apply play and song strategies at a small extent. Though the findings from hypothesis testing showed nonexistence of relationship, it is important for teachers to be skilled on different teaching strategies for them to effectively apply such strategies. It is important for teachers to be skilled on the application of different teaching strategies so as they can choose and apply the most appropriate strategy (Keller, Neumann, \& Fischer, 2017). Teachers with no such skills may either choose wrong strategies or fail to use the appropriate ones.

\section{Conclusions}

Play and song strategies are not effectively applied by preprimary teachers in Meru district while teaching prereading and pre-writing skills. Failure of these teachers to make effective use of play and song strategies affects the development of pre-reading and pre-writing skills among the preprimary pupils. This might account for the presence of students in later learning levels who do not know how to read or write. When pupils fail to achieve these skills at the lower ages, they may not be able to effectively achieve them in later years. Hence their general reading and writing abilities will be negatively affected.

Preprimary teachers in Meru district are less equipped with skills needed for them to effectively make use of play and song strategies. This might be due to the fact that most of them do not have background on early childhood education. Lack of skills and knowledge makes it difficult for these teachers to make use of play and song strategies. Due to this, teachers do make use of other strategies which they believe to be simple to use. Lack of training among teachers makes the application of play and song strategies not to be effective in the development of pre-reading and pre-writing skills among pre-primary pupils in Meru district.

\section{Recommendations}

Teachers should be equipped with the necessary knowledge and skills to apply play and song strategies when teaching pre reading and pre writing skills. This can be done by the government conducting seminars and workshops to preprimary teachers so as to equip them with these skills. The teachers also should strive to improve their professional competence by participating in different seminars and workshops for the purpose of enhancing their pedagogical and content competence.

The ministry of education and community also should ensure the availability of resources in the public primary schools so as to enable teachers to make use of paly and song strategies when teaching pre reading and pre writing skills. Resources necessary to facilitate the playing activities need to be supplied in the schools. The presence of adequate resource in the schools will improve the engagement of pupils in play activities and hence enhance the learning and understanding of pre reading and pre writing skills. 


\section{References}

i. Abdi, B., Malusu, J. M., \&Ogoti, E. (2020). Effectiveness of the Pre-Service Primary Teacher Education Programme in Preparing Teachers to Teach Reading Skill in Lower Primary School in Tanzania.

ii. Anney VN, Mmasa M, Ndunguru N (2016). Literacy and Numeracy Teaching in Tanzania Classrooms: Insights from Teachers' Classroom Practices. J. Educ. Pract., 7(9):137-154

iii. Baidoo, G. S. (2016). The use of Kinaesthetic Activities as art therapy tools to improve performance in pre-reading and pre-writing among kindergarten pupils [Thesis, Kwame Nkrumah of Science and Technology, Kumasi]. http://ir.knust.edu.gh:8080/handle/123456789/9273

iv. Budinski, V., \&Lujić, I. (2018). Preschool Teachers' Opinions on the Methodology of Teaching Activities for Developing Pre-Reading and Pre-Writing Skills. Croatian Journal of Education: HrvatskiČasopis Za Odgoj $i$ Obrazovanje, 20(Sp.Ed.2), 131-170. https://doi.org/10.15516/cje.v20i0.3119

v. Gathumbi AW (2013). Underachievement in Reading and Writing Skills and the Implications in Promoting LifeLong Learning. J. Education and Practice, 4(13):72-85.

vi. Harris, K. I., Kinley, H. L., \& Cook, A. (2017). Promoting alphabet knowledge using peer-mediated intervention: A dynamic duo for early literacy development. Young exceptional children, 20(2), 55-68.

vii. Jenkins, J. M., Farkas, G., Duncan, G. J., Burchinal, M., \&Vandell, D. L. (2016). Head Start at Ages 3 and 4 versus Head Start Followed by State Pre-K: Which Is More Effective? In Grantee Submission. https://doi.org/10.3102/0162373715587965

viii. Jung, C. G., Schmid-Guisan, H., \&Schmid-Guisan, H. (2012). The Question of Psychological Types. Princeton University Press.

ix. Keller, M. M., Neumann, K., \& Fischer, H. E. (2017). The Impact of Physics Teachers' Pedagogical Content Knowledge and Motivation on Students' Achievement and Interest. Journal of research in science teaching, 54(5), 586-614.

x. Klimova, B., Maresova, P., Valis, M., Hort, J., \&Kuca, K. (2015). Alzheimer's disease and language impairments: social intervention and medical treatment. Clinical interventions in aging, 10, 1401.

xi. Lesser, L. M., Pearl, D. K., Weber, J. J., Dousa, D. M., Carey, R. P., \& Haddad, S. A. (2019). Developing Interactive Educational Songs for Introductory Statistics. Journal of Statistics Education, 27(3), $238-252$. https://doi.org/10.1080/10691898.2019.1677533

xii. Ligembe NN (2014). Factors Affecting the Acquisition of Reading Skills in Kiswahili Primary Schools: The Case of Musoma Municipal and Misungwi District Councils. Unpublished Doctoral Thesis, The Open Ngussa and Chiza 193 University of Tanzania.

xiii. Manu, M., Torppa, M., Eklund, K., Poikkeus, A.-M., Lerkkanen, M.-K., \&Niemi, P. (2021). Kindergarten PreReading Skills Predict Grade 9 Reading Comprehension (PISA Reading) but Fail to Explain Gender Difference. Reading and Writing: An Interdisciplinary Journal, 34(3), 753-771. https://doi.org/10.1007/s11145-02010090-w

xiv. Matsumoto, H., \&Tsuneda, M. M. (2019). Teachers' beliefs about literacy practices for young children in early childhood education and care settings. International Journal of Early Years Education, 27(4), 441-456. https://doi.org/10.1080/09669760.2018.1547630

xv. Ministry of Education, Science and Technology (2019). Education sector Performance Report Tanzania Mainland.

xvi. MourãoJúnior, C. A., \& Faria, N. C. (2015). Memory. Psicologia: Reflexão e Crítica, 28(4), 780-788.

xvii. Musa, N. C., Lie, K. Y., \&Azman, H. (2012). Exploring English language learning and teaching in Malaysia. GEMA Online® Journal of Language Studies, 12(1).

xviii. Namamba, A., \&Rao, C. (2017). Preparation and Professional Development of Teacher Educators in Tanzania: Current Practices and Prospects. Journal of Education and Practice, 8(8), 136-145.

xix. Oluoch.G.P (2006). Essential of Curriculum Development. Dar es salaam: Longhorn Publisher.

xx. Onyango, N. C., \&Gakii, D. M. C. (2017). Influence of Instructional Strategies on Pre-School Children Transition to Lower Primary school. A case of Kikuyu Sub- Urban, Kenya. International Journal of Law, Humanities \& Social Science, 1(5), 39-45.

xxi. Osei, A. M., Liang, Q. J., Natalia, I., \& Stephen, M. A. (2016). The Use of Pre-Reading Activities in Reading Skills Achievement in Preschool Education. European Journal of Educational Research, 5(1), 35-42.

xxii. Paige, D. D., Smith, G. S., Rasinski, T. V., Rupley, W. H., Magpuri-Lavell, T., \& Nichols, W. D. (2019). A path analytic model linking foundational skills to Grade 3 state reading achievement. The Journal of Educational Research, 112(1), 110-120. https://doi.org/10.1080/00220671.2018.1445609

xxiii. Roskos, K. A., Christie, J. F., \&Richgels, D. J. (2003). The essentials of early literacy instruction. Young Children, 58(2), 52-60.

xxiv. Rusu, C., Wallace, R. 'Dickie,' Coman, M., Costea, V., Sidor, A., Pop, C., \&Navsaria, D. (2019). Attitudes and Practices of Pre-Reading and Early Childhood Literacy Promotion among Family Physicians in Romania. Journal of Early Childhood Literacy, 19(4), 459-486. https://doi.org/10.1177/1468798417728402

xxv. Shukia, R. (2019). Pre-primary Education in Tanzania: Teachers' Knowledge and Instructional Practices in Rural Areas. Huria: Journal of the Open University of Tanzania, 26(1).

xxvi. Strauss, A. M. (2017). A dialogical approach for improving early literacy teaching in multilingual pre-primary contexts [Thesis, University of Pretoria]. https://repository.up.ac.za/handle/2263/65470

xxvii. Tandika, P. B. (2017). Instructional Materials and the Development of Young Children's 21st Century Skills: 
Perspectives from Early Educators in Ukerewe, Tanzania. Journal of Research in Childhood Education, 1-15.

xxviii. Twaweza, E. A., \& Africa, T. E. (2017). Julius Atuhurra and Violet Alinda.

xxix. URT, (2000).Education in Global Era: Challenges to Equity, Opportunity for diversity. Paper presented at the fourteenth conference of Common Wealth Education Ministries. Halifax, Nova Scotia, Canada 27-30 November, 2000.

xxx. URT. (2018). Tanzania National Information and Communication Technology for Basic Education. Dar-es salaam: Ministry of Education, Science and Technology

xxxi. Uwezo. (2014). Are Our Children Learning? Literacy and Numeracy Across East Africa 2013. Nairobi: Twaweza.

xxxii. Uwezo. (2015). Are our children learning? Literacy and Numeracy in Tanzania 2014. Dar es Salaam: Twaweza East Africa.

xxxiii. Uwezo.net (2010). Are our children learning? Annual learning assessment report Tanzania 2010. Retrieved October 11, 2010 from http://www.uwezo.net.

xxxiv. Uwezo.net (2011). Are our children learning? Annual learning assessment report Tanzania 2011. Retrieved May 11, 2014 from http://www.uwezo.net.

xxxv. Uwezo.net (2012). Are our children learning? Annual learning assessment report Tanzania 2012. Retrieved April 11, 2014 from http://www.uwezo.net.

xxxvi. ZarfsazElham, \&Yeganehpour, P. (2021). The Effect of Timing of Pre-Reading Activities on High Intermediate EFL Learners' Reading Comprehension. Journal of Language and Linguistic Studies, 17, 702-716. 